\title{
Sequestration of free cholesterol in cell membranes by prions correlates with cytoplasmic phospholipase $A_{2}$ activation Clive Bate*, Mourad Tayebi and Alun Williams
}

Address: Department of Pathology and Infectious Diseases, Royal Veterinary College, Hawkshead Lane, North Mymms, Herts, AL9 7TA, UK

Email: Clive Bate* - cbate@rvc.ac.uk; Mourad Tayebi - mtayebi@rvc.ac.uk; Alun Williams - alunwilliams@rvc.ac.uk

* Corresponding author

Published: 12 February 2008

BMC Biology 2008, 6:8 doi:10.1 186/174|-7007-6-8

This article is available from: http://www.biomedcentral.com/174I-7007/6/8

(C) 2008 Bate et al; licensee BioMed Central Ltd.

This is an Open Access article distributed under the terms of the Creative Commons Attribution License (http://creativecommons.org/licenses/by/2.0), which permits unrestricted use, distribution, and reproduction in any medium, provided the original work is properly cited.
Received: 27 July 2007

Accepted: 12 February 2008

\begin{abstract}
Background: The transmissible spongiform encephalopathies (TSEs), otherwise known as the prion diseases, occur following the conversion of the normal cellular prion protein ( $\mathrm{PrPC})$ to an alternatively folded isoform (PrPSc). The accumulation of PrPSc within the brain leads to neurodegeneration through an unidentified mechanism. Since many neurodegenerative disorders including prion, Parkinson's and Alzheimer's diseases may be modified by cholesterol synthesis inhibitors, the effects of prion infection on the cholesterol balance within neuronal cells were examined.
\end{abstract}

Results: We report the novel observation that prion infection altered the membrane composition and significantly increased total cholesterol levels in two neuronal cell lines (ScGTI and ScN2a cells). There was a significant correlation between the concentration of free cholesterol in ScGTI cells and the amounts of PrPSc. This increase was entirely a result of increased amounts of free cholesterol, as prion infection reduced the amounts of cholesterol esters in cells. These effects were reproduced in primary cortical neurons by the addition of partially purified PrPSc, but not by $\mathrm{PrPC}$. Crucially, the effects of prion infection were not a result of increased cholesterol synthesis. Stimulating cholesterol synthesis via the addition of mevalonate, or adding exogenous cholesterol, had the opposite effect to prion infection on the cholesterol balance. It did not affect the amounts of free cholesterol within neurons; rather, it significantly increased the amounts of cholesterol esters. Immunoprecipitation studies have shown that cytoplasmic phospholipase $A_{2}\left(\mathrm{cPLA}_{2}\right)$ coprecipitated with PrPSc in ScGTI cells. Furthermore, prion infection greatly increased both the phosphorylation of $\mathrm{CPLA}_{2}$ and prostaglandin $\mathrm{E}_{2}$ production.

Conclusion: Prion infection, or the addition of PrPSc, increased the free cholesterol content of cells, a process that could not be replicated by the stimulation of cholesterol synthesis. The presence of PrPsc increased solubilisation of free cholesterol in cell membranes and affected their function. It increased activation of the PLA 2 pathway, previously implicated in PrPSc formation and in PrPsc-mediated neurotoxicity. These observations suggest that the neuropathogenesis of prion diseases results from $\mathrm{PrPSc}$ altering cholesterol-sensitive processes. Furthermore, they raise the possibility that disturbances in membrane cholesterol are major triggering events in neurodegenerative diseases. 


\section{Background}

Cholesterol levels within the brain may affect the pathogenesis of some neurodegenerative diseases including Alzheimer's and Parkinson's diseases and multiple sclerosis $[1,2]$. Neuronal cholesterol levels are also thought to affect the progression of the transmissible spongiform encephalopathies (TSEs), otherwise known as prion diseases [3]. These diseases are associated with the conversion of the normal cellular prion protein $\left(\mathrm{PrPC}^{\mathrm{C}}\right)$ to an alternatively folded isoform ( $\mathrm{PrPSc}$ ) [4]. The accumulation of PrPSc is closely associated with the main pathological features of TSEs: the spongiform degeneration of the brain, synaptic alterations, glial cell activation and extensive neuronal loss $[5,6]$. While a recent study reported that prion infection in vivo was associated with changes in brain cholesterol levels [7], the change in cholesterol regulation in neurons following prion infection has not been characterised extensively. Furthermore, because the brain is composed of diverse cell types, it is possible that changes in the cholesterol content of neurons may be obscured in mixed cell populations or whole brain studies. To reduce the problem of cell heterogeneity, the effects of prion infection on two neuronal cell lines were examined. We report that prion infection is associated with increased amounts of free cholesterol in the cell membrane, but also with reduced amounts of cholesterol esters suggesting that prion infection alters cholesterol regulation. The effects of prion infection on cholesterol balance were reproduced in primary cortical neurons incubated with exogenous PrPSc preparations.

Disturbing cholesterol metabolism within cells may have profound effects on cell function. Although cholesterol is a component of normal cell membranes, the amounts of free cholesterol are increased between three- and five-fold in specialised detergent-resistant micro-domains within the plasma membrane that are commonly called lipid rafts [8]. Such lipid rafts are also highly enriched in sphingolipids and gangliosides, and contain specific proteins [9]. The raft-associated proteins include many proteins attached to membranes via a glycosylphosphatidylinosi- tol (GPI) anchor [10] including both $\mathrm{PrPC}^{\mathrm{C}}$ and $\mathrm{PrPSc}$ [11]. In addition, cellular receptors for folate or the p75 neurotrophin receptor are found within rafts $[12,13]$, as are receptors for neurotransmitters including acetylcholine [14] and gamma-aminobutyric acid [15]. Such domains also contain components of signalling pathways including the Src family tyrosine kinases [16], adenylyl cyclase [17], the trimeric G-proteins [18] and cytoplasmic phospholipase $\mathrm{A}_{2}\left(\mathrm{CPLA}_{2}\right)$ [19]. Lipid rafts act as membrane platforms that concentrate molecules for cell signalling [20] and changes in membrane cholesterol levels may lead to abnormal cell signalling. As the neurotoxicity of $\mathrm{PrPSc}^{\mathrm{Sc}}$ was blocked by $\mathrm{PLA}_{2}$ inhibitors [21] the effects of prion infection on $\mathrm{PLA}_{2}$ activity was examined. Here we report increased activation (phosphorylation) of $\mathrm{CPLA}_{2}$ in ScGT1 cells.

\section{Results \\ Prion infection increased free cholesterol in neuronal cell lines}

The amounts of protein and cholesterol in two prioninfected neuronal cell lines (ScN2a and ScGT1 cells) were compared to that of uninfected controls (N2a and GT1 cells). There were no significant differences in the amounts of protein between infected and uninfected cells. In contrast, the amounts of total cholesterol (a mixture of free and esterified cholesterol) were significantly higher in infected ScGT1 cells than in GT1 cells (542 ng cholesterol/ mg protein \pm 44 versus $453 \pm 72, n=11, P=0.004$ ) (Table $1)$. More detailed analysis showed that the amounts of free cholesterol within ScGT1 cells were 36\% higher than those in GT1 cells $(500 \pm 54$ versus $368 \pm 59, n=11, P=$ 0.0003 ), while the amounts of esterified cholesterol were $50 \%$ less than in GT1 cells ( $42 \pm 14$ versus $85 \pm 28, n=11$, $P=0.0007)$. Similar results were obtained when ScN2a and N2a cells were compared: amounts of free cholesterol in ScN2a cells were 23\% higher than in N2a cells (473 \pm 41 versus $384 \pm 37, n=11, P=0.0001$ ), but the amounts of esterified cholesterol were significantly lower than those of N2a cells $(52 \pm 14$ versus $87 \pm 19, n=11, P=$ $0.002)$. Thus, in both cell lines prion infection was associ-

Table I: Prion infection increased the amounts of free cholesterol in neuronal cell lines. The amounts of total cholesterol, free cholesterol and esterified cholesterol (ng cholesterol/mg protein) in extracts from prion infected neuronal cells (ScN2a or ScGTI cells) compared with their non-infected counterparts (N2a or GTI cells). Values shown are the mean \pm SD from II samples.

Cholesterol (ng/mg protein)

Esterified

\begin{tabular}{ccccc} 
& Total (mean \pm SD) & Free (mean \pm SD) & Mean \pm SD & Percentage \\
\hline N2a & $472 \pm 47$ & $384 \pm 37$ & $87 \pm 19$ & $18 \pm 4$ \\
ScN2a & $525 \pm 34$ & $473 \pm 41$ & $52 \pm 14$ & $10 \pm 3$ \\
GTI & $453 \pm 72$ & $368 \pm 59$ & $85 \pm 28$ & $19 \pm 5$ \\
ScGTI & $542 \pm 44$ & $500 \pm 54$ & $42 \pm 14$ & $8 \pm 3$ \\
\hline
\end{tabular}


ated with a significant decrease in the amounts of cholesterol esters and in the percentage of cholesterol that was esterified (Table 1).

Brain-derived neurotrophic factor (BDNF) increased the PrPSc content of ScGT1 cells [22]. Here we report that treatment with BDNF, glial-derived neurotrophic factor (GDNF) or retinoic acid also increased the $\mathrm{PrPSc}^{\mathrm{Sc}}$ content of ScGT1 cells, while treatment with nerve-growth factor (NGF) did not (Table 2). The increased PrPsc content of treated ScGT1 cells was accompanied by increased amounts of free cholesterol. The free cholesterol content of ScGT1 cells was significantly higher in cells treated with BDNF (654 ng cholesterol/mg protein \pm 61 versus $510 \pm$ $48, n=9, P=0.003), \operatorname{GDNF}(655 \pm 59$ versus $510 \pm 48, n$ $=9, P=0.004)$ or retinoic acid $(705 \pm 83$ versus $510 \pm 48$, $n=9, P=0.002)$ but not in cells treated with NGF (503 \pm 72 versus $510 \pm 48, n=9, P=0.64)$. None of the treatments increased the cholesterol content of uninfected GT1 cells showing that the increases in free cholesterol were related to the PrPSc content of cells. To examine this relationship further, ScGT1 cells were treated with varying concentrations of GDNF and amounts of PrPSc and free cholesterol were measured. A significant correlation coefficient between the amounts of $\mathrm{PrPSc}$ and free cholesterol was observed $($ Pearson correlation $=0.922)$; see Figure 1 .

\section{PrPSc increases the free cholesterol content of cortical neurons}

As the above observations were on prion-infected neuronal cell lines, we sought to determine whether PrPSc had the same effect on non-transformed cells. Primary cortical neurons were incubated with sub-lethal amounts of PrPsc, or equivalent amounts of $\operatorname{PrPC}^{\mathrm{C}}$ for 48 hours. The addition of PrPsc increased the amounts of free cholesterol when compared with untreated cells or cells treated with $\mathrm{PrPC}$ (Figure 2). The amounts of free cholesterol were significantly higher in neurons treated with $100 \mathrm{pg} / \mathrm{ml} \mathrm{PrPSc}$ than in untreated cells $(704 \mathrm{ng} / \mathrm{mg}$ protein \pm 73 versus $504 \pm 58, n=9, P=0.0019)$. Similarly, the amounts of free

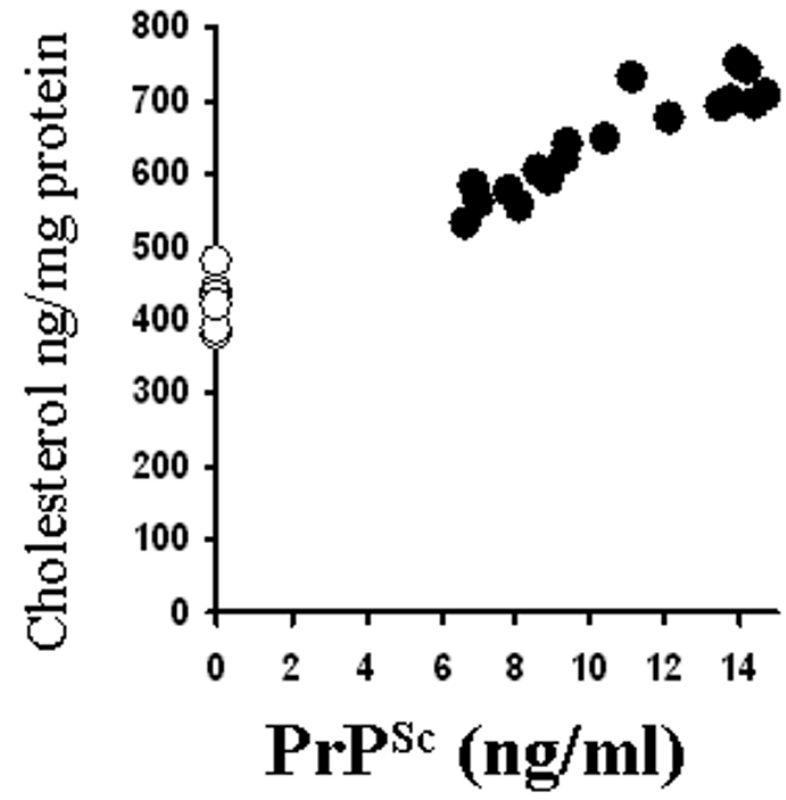

Figure I

Correlation between the amounts of PrPSc and free cholesterol in ScGTI cells. The amounts of PrPSc in GTI cells $(O)$ or ScGTI cells $(\mathbf{)}$ treated with varying amounts of GDNF for 7 days were plotted against the amounts of free cholesterol in the same cells (expressed as ng cholesterol/mg protein).

cholesterol were significantly higher in neurons treated with $20 \mathrm{pg} / \mathrm{ml} \mathrm{PrPSc}(632 \pm 46$ versus $504 \pm 58, n=9, P=$ $0.004)$. There was no significant difference in the amounts of free cholesterol in untreated neurons and in neurons incubated with $100 \mathrm{pg} / \mathrm{ml} \mathrm{PrPC}(504 \pm 58$ versus $517 \pm 46$, $n=9, P=0.51)$.

Table 2: Correlation between PrPSc and free cholesterol content in ScGTI cells. The amounts of PrPSc and free cholesterol in ScGTI and GTI cells treated for 7 days with neurotrophic factors or retinoic acid as shown. Free cholesterol was measured in cell extracts using the Amplex Red cholesterol assay kit. Values shown are the mean \pm SD from 9 samples. PrPSc content of cells significantly greater than those of untreated cells $(P<0.05)$ are indicated by * and free cholesterol content of cells significantly greater than those of untreated cells $(P<0.05)$ are indicated by \#.

\begin{tabular}{|c|c|c|c|c|}
\hline & \multicolumn{2}{|c|}{$\operatorname{PrPSc}(\mathrm{ng} / \mathrm{ml})$} & \multicolumn{2}{|c|}{ Free cholesterol (ng/mg protein) } \\
\hline & ScGT I & GT I & ScGTI & GTI \\
\hline Control & $6.9 \pm 0.2$ & - & $510 \pm 48$ & $392 \pm 44$ \\
\hline $10 \mathrm{ng} / \mathrm{ml}$ BDNF & $15.2 \pm 1.4^{*}$ & - & $654 \pm 61 \#$ & $417 \pm 43$ \\
\hline $10 \mathrm{ng} / \mathrm{ml}$ GDNF & $14.2 \pm 0.5^{*}$ & - & $655 \pm 59 \#$ & $393 \pm 32$ \\
\hline $10 \mathrm{ng} / \mathrm{ml} \mathrm{NGF}$ & $7.4 \pm 1.7$ & - & $503 \pm 72$ & $364 \pm 45$ \\
\hline $100 \mathrm{nM}$ retinoic acid & $16.5 \pm 2.1^{*}$ & - & $705 \pm 83 \#$ & $440 \pm 59$ \\
\hline
\end{tabular}




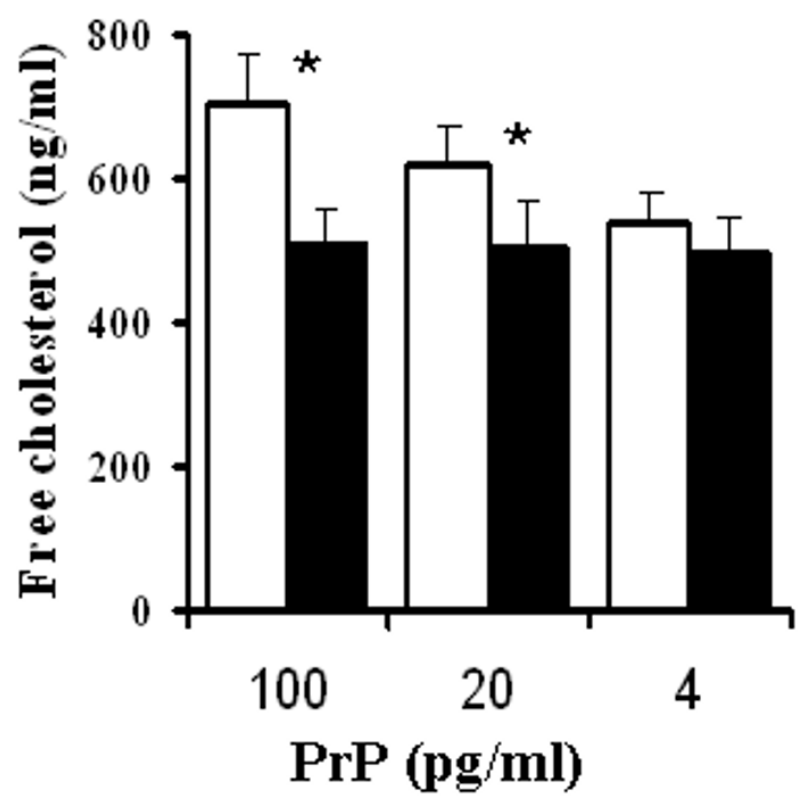

Figure 2

PrPSc causes a dose-dependent increase in the free cholesterol concentration of cortical neurons. The amounts of free cholesterol expressed as ng cholesterol/mg protein in cortical neurons treated for $\mathbf{4 8}$ hours with varying concentrations of $\operatorname{PrPC}(\square)$ or $\operatorname{PrPSc}(\square)$. Amounts of free cholesterol significantly greater than those of untreated neurons $(P<0.05)$ are indicated with *.

\section{Stimulating cholesterol synthesis increases cholesterol} esters but not free cholesterol in neurons

The possibility that prion infection stimulated cholesterol synthesis was examined by comparing the effects of $\mathrm{PrPSc}$ with those of increased cholesterol biosynthesis in cortical neurons. Mevalonate is a precursor of cholesterol synthesis that is a product of 3-hydroxy-3-methylglutaryl coenzyme A (HMG-CoA) reductase, the rate-limiting step in cholesterol synthesis [23]. Treatment with $100 \mu \mathrm{M}$ mevalonate significantly increased the amounts of total cholesterol in neurons (562 $\mathrm{ng}$ cholesterol/mg protein \pm 45 versus $482 \pm 54, n=9, P=0.001)$; this increase consisted primarily of cholesterol esters $(96 \pm 25$ versus $42 \pm 24, n=$ $9, P=0.006)$ as the amounts of free cholesterol were unchanged ( $466 \pm 50$ versus $440 \pm 46, n=9, P=0.16)$. Similar results were obtained in cells treated with $10 \mu \mathrm{M}$ cholesterol, which increased the amounts of cholesterol esters $(130 \pm 55$ versus $42 \pm 24, n=9, P=0.001)$ but not free cholesterol $(446 \pm 36$ versus $440 \pm 46, n=9, P=0.54)$; see Figure 3 . The percentage of cholesterol that was esterified in untreated cells $(9 \% \pm 4)$ was raised to $17 \% \pm 5$ in neurons incubated with mevalonate, and $22 \% \pm 8$ in neurons treated with cholesterol. The addition of mevalonate

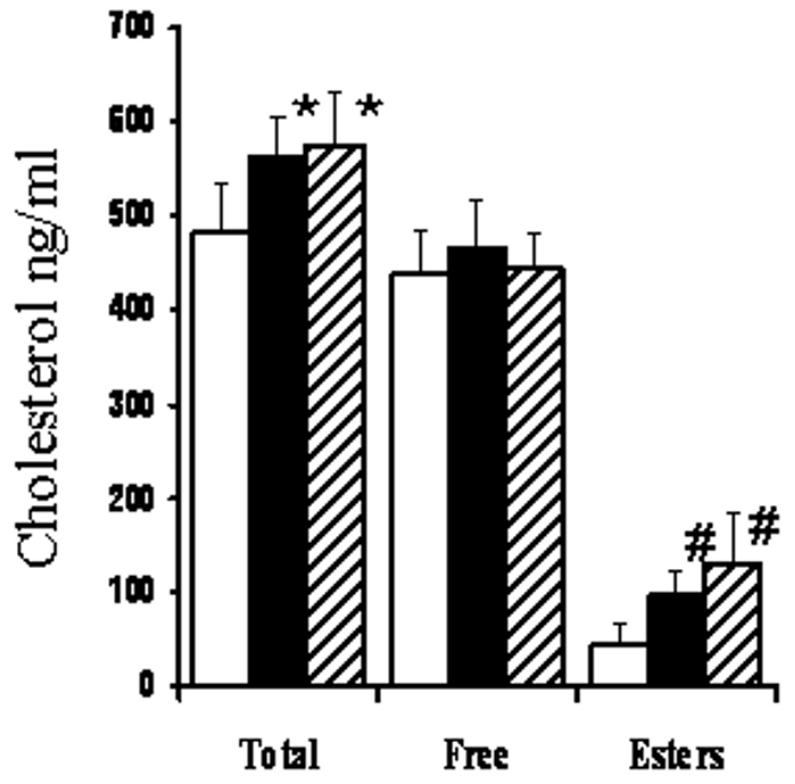

Figure 3

Regulation of free cholesterol in cortical neurons. The amounts of total cholesterol, free cholesterol and cholesterol esters, all expressed as $\mathrm{ng}$ cholesterol/mg protein in cortical neurones treated for 24 hours in control medium (open bars), $100 \mu \mathrm{M}$ mevalonate (black bars) or $50 \mu \mathrm{M}$ cholesterol (striped bars). Amounts of total cholesterol significantly greater than those of untreated neurons $(P<0.05)$ are indicated with $*$ and amounts of cholesterol esters significantly greater than those of untreated neurons $(P<0.05)$ are indicated with \#.

or cholesterol did not affect the protein content of cell extracts.

\section{Prion infection increased activation of $C P L A_{2}$ in neuronal cell lines}

As lipid rafts act as platforms in which signalling complexes assemble [24], the possibility that the altered composition of lipid rafts in prion-infected cells affected cell signalling was examined. More specifically, as $\mathrm{PLA}_{2}$ was required for prion formation [25], the amounts of activated $\mathrm{CPLA}_{2}$ in cells were examined. The amounts of activated (phosphorylated) $\mathrm{CPLA}_{2}$ in ScGT1 cells were greater than those in GT1 cells (Figure 4A). The relationship between activated $\mathrm{CPLA}_{2}$ and $\mathrm{PrPSc}^{\mathrm{Sc}}$ was examined in ScGT1 cells treated with different neurotrophins or retinoic acid. The increased PrPSc content of treated ScGT1 cells was accompanied by increased amounts of activated $\mathrm{CPLA}_{2}$. The amounts of activated cPLA ${ }_{2}$ in ScGT1 cells was significantly higher in cells treated with BDNF (514 units/ml \pm 69 versus $395 \pm 33, n=9, P=0.01)$, GDNF ( $542 \pm 65$ versus $395 \pm 33, n=9, P=0.008)$ or retinoic acid $(553 \pm 79$ 
versus $395 \pm 33, n=9, P=0.01$ ) but not in cells treated with NGF ( $416 \pm 46$ versus $395 \pm 33, n=9, P=0.41)$. In contrast, none of these treatments significantly increased the amounts of activated CPLA ${ }_{2}$ in GT1 cells showing that increased activation of $\mathrm{CPLA}_{2}$ is related to the $\mathrm{PrPSc}^{\mathrm{PS}}$ content of cells (Table 3 ). The relationship between $\mathrm{CPLA}_{2}$ and $\mathrm{PrPSc}^{\mathrm{S}}$ as examined further in ScGT1 cells treated with varying concentrations of GDNF. The correlation coefficient between the amounts of $\mathrm{PrPSc}^{\mathrm{P}}$ in cells and the amounts of activated $\mathrm{CPLA}_{2}$ was significant (Pearson correlation = 0.865 ); see Figure $4 \mathrm{~B}$.

Confirmation of increased PLA 2 activity in ScGT1 cells was provided by observations that the amounts of $\mathrm{PGE}_{2}$ produced by ScGT1 cells were significantly higher than that of GT1 cells $\left(318 \mathrm{pg} / \mathrm{ml} \mathrm{PGE}_{2} \pm 46\right.$ versus $134 \pm 37, n=6, P$ $=0.000004)$. Similarly, the amounts of $\mathrm{PGE}_{2}$ produced by ScN2a cells were significantly higher than that of N2a cells $(253 \pm 40$ versus $118 \pm 13, n=6, P=0.0003)$. To ensure that $\mathrm{PGE}_{2}$ was produced via the $\mathrm{PLA}_{2} /$ cyclo-oxygenase pathway, ScGT1 cells were treated with PLA $_{2}$ or cyclo-oxygenase inhibitors. The addition of the PLA $\mathrm{PL}_{2}$ inhibitors reduced $\mathrm{PGE}_{2}$ production in ScGT1 cells; treatment with 1 $\mu \mathrm{M} \mathrm{AACOCF} 3$ reduced $\mathrm{PGE}_{2}$ levels from $318 \pm 46$ to $98 \pm$ $28, n=6, P=0.000002$, while $1 \mu \mathrm{g} / \mathrm{ml}$ aristolochic acid reduced $\mathrm{PGE}_{2}$ production to $124 \pm 36, n=6, P=0.00001$. Cyclo-oxygenase inhibitors also reduced $\mathrm{PGE}_{2}$ production, $100 \mathrm{nM}$ acetyl-salicylic acid reduced $\mathrm{PGE}_{2}$ levels from $318 \pm 46$ to $59 \pm 34, n=6, P=0.0000005$, and 500 nM ibuprofen reduced $\mathrm{PGE}_{2}$ production to $110 \pm 40, n=$ $6, P=0.00007$.

\section{Rafts containing PrPSc also contain CPLA 2}

Immunoprecipitation was used to determine whether $\mathrm{CPLA}_{2}$ was associated with PrP-containing lipid rafts in ScGT1 cells. Mab 4F2, which recognises both $\mathrm{PrPC}^{\mathrm{C}}$ and $\mathrm{PrPSc}$, precipitated $\mathrm{CPLA}_{2}$ out of membrane extracts from untreated ScGT1 cells. Two methods were used to show that $\mathrm{CPLA}_{2}$ was associated with $\mathrm{PrPSc}^{\mathrm{Sc}}$ rather than $\mathrm{PrPC}^{\mathrm{C}}$ in these ScGT1 cell extracts. First, immunoprecipitation with mab IC18, which recognises $\mathrm{PrPC}^{\mathrm{C}}$ but not PrPSc, did not

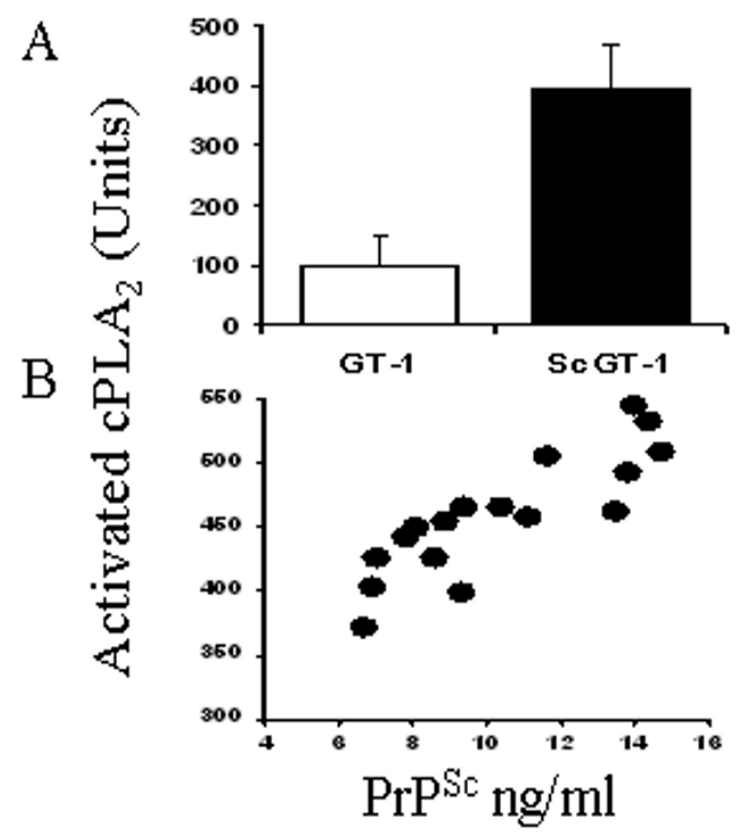

Figure 4

Prion infection increases the amounts of activated cPLA $\mathbf{A}_{2}$ in ScGT I cells. (A) The amounts of activated CPLA 2 in cell extracts from I $\times 10^{6} \mathrm{GTI}$ cells (open bars) or ScGT I cells (black bars). Values shown are the mean \pm SD from 10 samples. (B) The amounts of activated cPLA ${ }_{2}$ in ScGTI cells treated with varying concentrations of GDNF for 7 days $(\mathbf{O})$ were plotted against the amounts of PrPSc in the same cells.

precipitate $\mathrm{CPLA}_{2}$ from ScGT1 cells. Second, immunoprecipitation with mab $4 \mathrm{~F} 2$ precipitated $\mathrm{CPLA}_{2}$ from ScGT1 cells from which $\mathrm{PrP}^{\mathrm{C}}$ had been removed following treatment with PI-PLC (Figure 5A). A mab to CD55, or an IgG isotype control, did not precipitate $\mathrm{CPLA}_{2}$ from ScGT1 cells. Next we examined the distribution of activated $\mathrm{cPLA}_{2}$ within ScGT1 cells. The amounts of activated cPLA 2 in whole cell extracts $(100 \%)$ were compared with those in membranes precipitated with mab $4 \mathrm{~F} 2$ and to the depleted membrane extract. Greater than $60 \%$ of activated

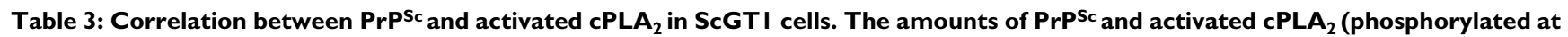
serine 505) in ScGTI and GTI cells treated for 7 days with neurotrophic factors or retinoic acid as shown. Values shown are the mean \pm SD from 9 samples. PrPSc content of cells significantly greater than those of untreated cells $(P<0.05)$ are indicated by $*$ and amounts of activated cPLA $A_{2}$ significantly greater than those of untreated cells $(P<0.05)$ are indicated by \#.

\begin{tabular}{|c|c|c|c|c|}
\hline & \multicolumn{2}{|c|}{$\operatorname{PrPSc}(n g / m l)$} & \multicolumn{2}{|c|}{ Activated cPLA (units) } \\
\hline & ScGT I & GT I & ScGT I & GT I \\
\hline Control & $6.9 \pm 0.2$ & - & $395 \pm 33$ & $100 \pm 18$ \\
\hline $10 \mathrm{ng} / \mathrm{ml}$ BDNF & $15.2 \pm 1.4^{*}$ & - & $514 \pm 69 \#$ & $102 \pm 7$ \\
\hline $10 \mathrm{ng} / \mathrm{ml}$ GDNF & $14.2 \pm 0.5^{*}$ & - & $542 \pm 65^{\#}$ & $109 \pm 9$ \\
\hline $10 \mathrm{ng} / \mathrm{ml}$ NGF & $7.4 \pm 1.7$ & - & $416 \pm 46$ & $98 \pm 6$ \\
\hline 100 nM retinoic acid & $16.5 \pm 2.1 *$ & - & $553 \pm 79 \#$ & $113 \pm 13$ \\
\hline
\end{tabular}



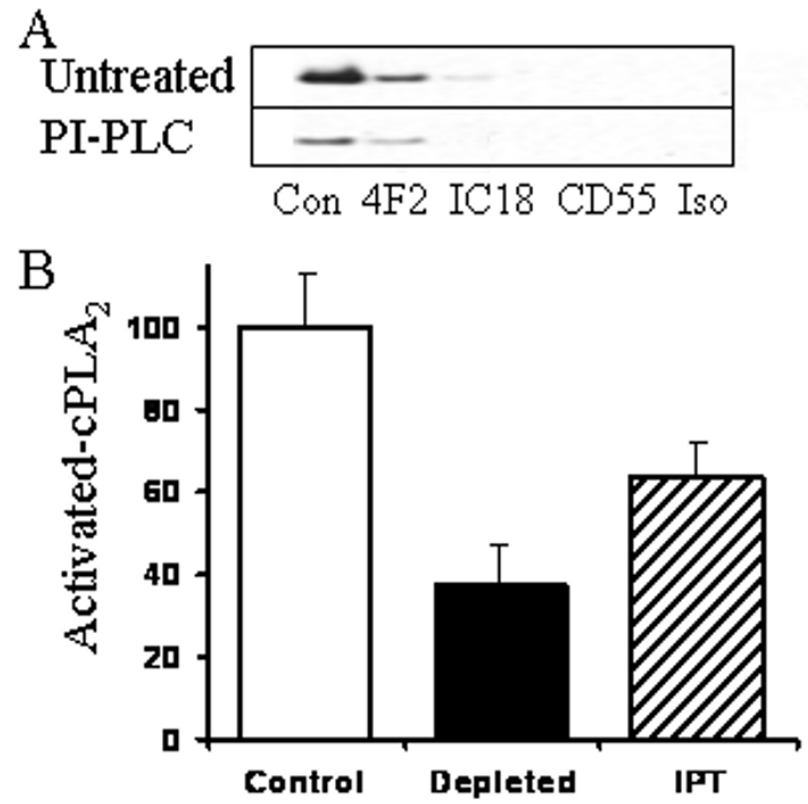

Figure 5

Activated cPLA $A_{2}$ is associated with PrPSc in ScGT I cells. (A) Immunoblots showing amounts of $c P L A_{2}$ immunoprecipitated with antibodies to PrP (4F2 or ICI8), CD55 or an isotype control (Iso) from untreated ScGTI cells (Untreated) or from ScGTI cells pre-treated with 0.2 units PI-PLC for 30 minutes (PI-PLC). (B) The amounts of activated $\mathrm{cPLA}_{2}$ (expressed as a percentage) in whole cell extracts from ScGTI cells (open bars), from ScGTI cell extracts depleted with the anti-PrP mab 4F2 (black bars) and in 4F2 immunoprecipitates (IPT) from ScGTI cell extracts (striped bars). Values shown are the mean \pm SD from 10 samples.

$\mathrm{CPLA}_{2}$ was found in the immunoprecipitated membrane fraction (Figure 5B).

\section{Discussion}

The major goal of this study was to investigate the impact of $\mathrm{PrPSc}^{\mathrm{S}}$ on the biochemistry of cell membranes. The amounts of total cholesterol in membranes were significantly higher in prion-infected cell lines than in their uninfected counterparts and there was a significant correlation between amounts of cholesterol and PrPSc. More specifically, prion infection was associated with a significant increase in the amounts of free cholesterol. While much of what is known about the role of cholesterol in cell membranes is surmised from the changes in cells brought about by cholesterol depletion, either from cholesterol synthesis inhibitors or via cholesterol extraction, little is known about how neurons respond when the cholesterol content of membranes is increased.
How the presence of prions affects cholesterol levels remains to be determined. A synthetic prion-derived peptide activated HMG-CoA reductase suggesting a mechanism by which prion infection increased cholesterol production [26]. However, we were unable to replicate the effects of prion infection in non-infected cells by stimulating cholesterol biosynthesis or by adding exogenous cholesterol. The addition of mevalonate or cholesterol did not increase the amounts of free cholesterol in cell membranes; rather, they increased the amounts of cholesterol esters. This contrasts with the situation in prion-infected cells where the amounts of cholesterol esters were reduced. Cholesterol in cells is found either as free cholesterol in membranes or as cholesterol esters in cytoplasmic droplets. A dynamic equilibrium between the pools of free cholesterol and cholesterol esters is tightly controlled by acyl-coenzyme A:cholesterol acyltransferase (ACAT), an endoplasmic reticulum (ER)-resident enzyme that catalyses the formation of cholesterol esters from cholesterol and long-chain fatty acids [27]. In uninfected cells excess free cholesterol activates ACAT resulting in increased production of cholesterol esters. In these cells, increased free cholesterol levels were only seen following the addition of a combination of free cholesterol and an ACAT inhibitor (data not shown).

The situation in prion-infected cells, where the increased amounts of free cholesterol is accompanied by reduced amounts of cholesterol esters, is unusual. The increase in free cholesterol and the reduction of cholesterol esters in prion-infected cells may be a result of direct inhibition of ACAT or by sequestration of cholesterol in micro-environments that avoid ACAT. The amount of cholesterol in cell membranes is partly determined by its fatty acid composition. The high incidence of saturated fatty acids attached to sphingolipids, gangliosides and GPI-anchored proteins allows tight molecular packing and increases the solubilisation of free cholesterol [28]. Thus, the formation of $\mathrm{PrPSc}^{\mathrm{S}}$ may have a direct effect on the composition of cell membranes as the self-aggregation of $\mathrm{PrPSc}^{\mathrm{Sc}}$ results in the clustering of GPI anchors attached to PrPSc. The increased density of saturated fatty acids within $\mathrm{PrPs}^{\mathrm{Sc}}$-containing micro-domains encourages the solubilisation of free cholesterol and the remodelling of those membranes.

Increasing the free cholesterol content of membranes is thought to reduce membrane fluidity and subsequently affect the endocytosis and trafficking of proteins. Therefore, the formation of $\mathrm{PrPSc}^{\mathrm{Sc}}$ may alter conventional lipid raft structure and the $\mathrm{PrPC}^{\mathrm{C}}$-protein interactions that occur within lipid rafts. For example, $\mathrm{PrPC}^{\mathrm{C}}$ has been reported to bind to caveolin-1 [29] or N-CAM [30], proteins that reside within lipid rafts. It is unclear whether these protein-protein interactions are affected following the conversion of $\mathrm{PrPC}^{\mathrm{C}}$ to $\mathrm{PrPS}$. The sequestration of free 
cholesterol into PrPsc-containing lipid rafts may deplete free cholesterol from other cellular pools where it helps to stabilise the packing of sphingolipids, gangliosides and raft-associated proteins in the membrane. This may affect the function of such proteins. For example, free cholesterol affects the formation and function of synapses [31]. Therefore, sequestration of cholesterol by PrPSc may affect synaptic transmission, a hypothesis supported by observations that ScGT1 cells contain altered amounts of synaptic proteins including synaptophysin [32] and that synapse damage is seen during the early stages of experimental prion diseases [6].

Cholesterol-dependent micro-domains are increasingly implicated as platforms necessary for cell signalling [24] and scrapie infections of neuronal cells are associated with increased levels of Src kinase [33]. The activation of $\mathrm{PLA}_{2}$ that is necessary for prion formation [25] is reduced in cholesterol-depleted cells suggesting that this enzyme may reside within a lipid raft [34]. Here we show that ScGT1 cells contained four times as much activated cPLA as GT1 cells and there was a significant correlation between amounts of activated $\mathrm{CPLA}_{2}$ and $\mathrm{PrPSc}^{\mathrm{S}}$ Immunoprecipitation studies showed that activated $\mathrm{CPLA}_{2} \mathrm{CO}-$ localised with PrPSc-containing lipid rafts in ScGT1 cells. Previous studies showed that cell activation results in the translocation of $\mathrm{CPLA}_{2}$ to endoplasmic and plasma membranes [35]. Our observations are consistent with the hypothesis that prion infection stimulates the translocation of CPLA ${ }_{2}$ to lipid rafts containing PrPSc. The activation of $\mathrm{CPLA}_{2}$ is associated with the production of prostaglandins and the amounts of $\mathrm{PGE}_{2}$ produced by ScGT1 cells were significantly higher than that of GT1 cells. Our observation that pre-treatment of ScGT1 cells with $\mathrm{PLA}_{2}$ or cyclo-oxygenase inhibitors reduced $\mathrm{PGE}_{2}$ production showed that $\mathrm{PGE}_{2}$ was a valid measure of $\mathrm{PLA}_{2}$ activity in these cells. These findings are consistent with reports of increased $\mathrm{PGE}_{2}$ in murine scrapie [36] and raised levels of $\mathrm{PGE}_{2}$ in the cerebrospinal fluid of patients with Creutzfeldt-Jakob disease [37].

\section{Conclusion}

We have demonstrated that the presence of $\mathrm{PrPSc}^{\mathrm{S}}$ increased the free cholesterol content of cell membranes. The increased free cholesterol could not be replicated by the stimulation of cholesterol synthesis or by the addition of exogenous free cholesterol, which increased the amounts of cholesterol esters. Our observations are consistent with the hypothesis that the clustering of saturated fatty acids, parts of the GPI anchors attached to PrPSc, increased the amounts of free cholesterol solubilised within the plasma membrane which increased membrane rigidity. These changes in cell membranes could reduce endocytosis and the recycling of cholesterol through the ER where it is exposed to ACAT, consistent with reduced cholesterol ester production in infected cells. The increased amounts of free cholesterol in the plasma membrane were associated with increased activation of the $\mathrm{PLA}_{2}$ pathway that is necessary for $\mathrm{PrPSc}^{\mathrm{S}}$-mediated neurotoxicity. This is a rare example of an infective agent increasing free cholesterol levels within cell membranes and raises the possibility that disturbances in membrane cholesterol are major triggering events in neurodegenerative diseases.

\section{Methods \\ Cell lines}

Prion-infected ScGT1 cells, from a murine hypothalamic neuronal cell line infected by the Chandler scrapie isolate and ScN2a neuroblastoma cells, were grown in Hams F12 medium supplemented with $2 \mathrm{mM}$ glutamine, $2 \%$ foetal calf serum (FCS) and standard antibiotics (100 U/ml penicillin and $100 \mu \mathrm{g} / \mathrm{ml}$ streptomycin; Invitrogen, Paisley, UK). Uninfected N2a or GT1 cells were used as noninfected controls and grown in the same medium. To determine the effect of neurotrophins or retinoic acid, cells were plated at $1 \times 10^{5}$ cells/well in 6 well plates. Cells were then grown with daily changes of media for 7 days.

\section{Neuronal cultures}

Primary cortical neurons were prepared from the brains of mouse embryos (day 15.5) after mechanical dissociation, cell sieving and isolation on histopaque (Sigma). Neuronal precursors were plated $(1,000,000$ cells/well in 24 well plates coated with $5 \mu \mathrm{g} / \mathrm{ml}$ poly-L-lysine) in Hams F12 containing 5\% FCS for 2 hours. Cultures were shaken (600 rpm for 5 minutes) and non-adherent cells removed by two washes in phosphate buffered saline (PBS). Neurons were grown in neurobasal medium (NBM) containing B27 components (Invitrogen) for 7 days and subsequently incubated with test compounds. Immunolabelling studies showed that after 7 days cultures contained less than 5\% glial cells (about 3\% GFAP positive and less than $1 \%$ MAC-1 positive cells).

\section{Cell extracts}

At the end of the treatment, cells were washed twice in PBS and homogenised in an extraction buffer containing 10 $\mathrm{mM}$ Tris- $\mathrm{HCl}, 100 \mathrm{mM} \mathrm{NaCl}, 10 \mathrm{mM}$ EDTA, 0.5\% Nonidet P-40, $0.5 \%$ sodium deoxycholate and $0.2 \%$ sodium dodecyl sulphate (SDS) at $1 \times 10^{6}$ cells/ml. Mixed protease inhibitors (AEBSF, Aprotinin, Leupeptin, Bestain, Pepstatin A and E-46; from Sigma) were added to some cell extracts. Membranes were prepared by repeated passage with a Wheaton homogeniser; nuclei and large fragments were removed by centrifugation $(300 \times g$ for 5 minutes $)$. To determine the amount of PrPsc in cells these supernatants were digested with $1 \mu \mathrm{g} / \mathrm{ml}$ proteinase $\mathrm{K}$ for 1 hour at $37^{\circ} \mathrm{C}$, digestion was stopped with mixed protease inhibitors. The soluble material was heated to $95^{\circ} \mathrm{C}$ for 5 
minutes and tested in a PrP specific enzyme-linked immunosorbent assay (ELISA).

\section{PrP ELISA}

The amount of PrP present in cell extracts was determined in a sandwich ELISA using a capture mab (ICSM18 which recognises amino acids 146 to 159 of murine PrP). Samples were applied and detected with biotinylated mab ICSM35 (which recognises a region between amino acids 91 and 110). Biotinylated mab was detected using extravidin-alkaline phosphatase and $1 \mathrm{mg} / \mathrm{ml}$ 4-nitrophenyl phosphate in a diethanolamine buffer (Sigma). Absorbance was measured on a microplate reader at $450 \mathrm{~nm}$ and the amount of PrP in cell extracts was calculated by reference to a standard curve of recombinant murine PrP (Prionics, Zurich, Switzerland); its limit of detection was 0.05 $\mathrm{ng} / \mathrm{ml}$.

\section{Cholesterol and protein content}

Cellular cholesterol and protein content were determined in cell extracts $\left(1 \times 10^{6}\right.$ cells $\left./ \mathrm{ml}\right)$. Protein concentrations were measured using a micro-BCA protein assay kit (Pierce, Cramlington, UK). The amounts of cholesterol were measured using the Amplex Red cholesterol assay kit (Invitrogen), according to the manufacturer's instructions. Briefly, cholesterol is oxidised by cholesterol oxidase to yield hydrogen peroxide and ketones. The hydrogen peroxide reacts with 10-acetyl-3, 7-dihydroxyphenoxazine (Amplex Red reagent) to produce highly fluorescent resorufin, which is measured by excitation at 550 $\mathrm{nm}$ and emission detection at $590 \mathrm{~nm}$. By performing the assay in the presence or absence of cholesterol esterase ( 50 units $/ \mathrm{ml}$ ) the assay can also determine the amounts of esterified cholesterol within samples.

\section{Isolation of PrPSc/PrPC}

$\mathrm{PrPC}^{\mathrm{C}}$ was extracted from uninfected GT1 cells by immunoprecipitation with a PrP-specific mab 4F2 and magnetic protein $\mathrm{G}$ beads followed by reverse-phase chromatography on a C18 column and a gradient of acetonitrile in water and $0.1 \%$ triflouroacetic acid. PrPSc was extracted from ScGT1 cells. Infectious cell extracts were digested with $1 \mu \mathrm{g} / \mathrm{ml}$ proteinase $\mathrm{K}\left(37^{\circ} \mathrm{C}, 1\right.$ hour $)$ and $\operatorname{PrPsc}^{\mathrm{Sc}}$ was precipitated with mab $4 \mathrm{~F} 2$ and magnetic protein $\mathrm{G}$ beads. $\mathrm{PrPSC}^{\mathrm{Sc}}$ was subsequently isolated by reverse-phase chromatography as above. The amounts of $\mathrm{PrPsc} / \mathrm{PrPC}$ in different fractions were quantified by a PrP-specific ELISA.

\section{cPLA $A_{2}$ ELISA}

The activation of $\mathrm{CPLA}_{2}$ is accompanied by phosphorylation of the 505 serine residue, which can be measured by phospho-specific antibodies. The amounts of activated $\mathrm{CPLA}_{2}$ in cell extracts were measured by a sandwich ELISA. Nunc Maxisorb immunoplates were coated with $0.5 \mu \mathrm{g} /$ $\mathrm{ml}$ of mouse mab anti-cPLA ${ }_{2}$, clone $\mathrm{CH}-7$ (Upstate, Mil- ton Keynes, UK) in carbonate buffer for 1 hour and blocked with $10 \%$ FCS. Samples were incubated for 1 hour at room temperature and the amounts of activated ${ }_{C P L A}$ were detected using a rabbit polyclonal anti-phos-

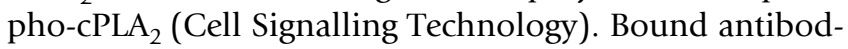
ies were detected with biotinylated anti-rabbit IgG (Dako, Ely, UK), extravidin-alkaline phosphatase and $1 \mathrm{mg} / \mathrm{ml} 4$ nitrophenyl phosphate in a diethanolamine buffer. Absorbance was measured at $450 \mathrm{~nm}$ and the amounts of activated $\mathrm{cPLA}_{2}$ were calculated from a standard curve using nonlinear regression. Samples were expressed as 'units $\mathrm{CPLA}_{2}$ ' where a measure of 100 units was defined as the amount of $\mathrm{CPLA}_{2}$ in $1 \times 10^{6}$ untreated GT1 cells. A standard curve was generated from this sample using sequential $\log 2$ dilutions (range 100 to 1.56 units/well).

\section{PGE $_{2}$ assay}

The amounts of $\mathrm{PGE}_{2}$ produced by cells were determined by using an enzyme-immunoassay kit (Amersham Biotech, Amersham, UK) according to the manufacturer's instructions. This assay is based on competition between unlabelled $\mathrm{PGE}_{2}$ in the sample and a fixed amount of labelled $\mathrm{PGE}_{2}$ for a $\mathrm{PGE}_{2}$ specific antibody. The detection limit of this assay is $20 \mathrm{pg} / \mathrm{ml}$.

\section{Immunoprecipitations}

Cells were washed in ice-cold PBS and incubated with antibodies against decay accelerating factor (DAF; CD55, mab BRIC 216, Bio-Products, Elstree, UK), PrP (mabs 4F2, ICSM18) or an isotype control in ice-cold PBS containing $5 \%$ FCS. In some experiments ScGT1 cells were pretreated with 0.2 units/ml PI-PLC for 1 hour prior to immunoprecipitation to remove surface $\mathrm{PrPC}^{\mathrm{C}}$. After 30 minutes cells were washed 5 times in ice-cold PBS and solubilised with $1 \%$ Triton $\times 100,10 \mathrm{mM}$ Tris- $\mathrm{HCl}, 100 \mathrm{mM}$ $\mathrm{NaCl}, 10 \mathrm{mM}$ EDTA and protease inhibitors at $1 \times 10^{6}$ cells/ml for 1 hour at $4{ }^{\circ} \mathrm{C}$ (this detergent solubilises the normal cell membrane but does not affect lipid raft microdomains). Cell debris was removed from membrane preparations by centrifugation ( $300 \times g$ for 5 minutes) and the supernatant was incubated with $\mu$ MACS protein G microbeads $(10 \mu \mathrm{l} / \mathrm{ml}$; Miltenyi Biotech, Bisley, UK) for 30 minutes. Protein G bound antibody complexes were isolated using a $\mu$ MACS magnetic system and standard protocols (Miltenyi Biotech). For ELISA studies proteins were eluted in $10 \mathrm{mM}$ Tris-HCL, $150 \mathrm{mM} \mathrm{NaCl}, 10 \mathrm{mM}$ EDTA, $0.5 \%$ Nonidet P-40, $0.5 \%$ sodium deoxycholate, $0.2 \%$ SDS and mixed protease inhibitors at $1 \times 10^{6} \mathrm{cells} /$ $\mathrm{ml}$. Other beads were boiled for 5 minutes in Laemmli buffer (Bio-Rad) and subjected to electrophoresis on a $15 \%$ polyacrylamide gel. Proteins were transferred onto a Hybond-P PVDF membrane (Amersham Biotech, UK) by semi-dry blotting. Membranes were blocked using $10 \%$ milk powder and CPLA $_{2}$ was detected by mab $\mathrm{CH}-7$. Bound antibody was detected by a secondary anti-mouse 
IgG conjugated to peroxidise and an enhanced chemiluminescence kit (Amersham Biotech).

\section{Reagents}

Mevalonate and $\mathrm{AACOCF}_{3}$ were bought from Calbiochem, Nottingham, UK. Acetyl salicylic acid, ibuprofen, MAPF, cholesterol, retinoic acid, BDNF, GDNF and NGF were obtained from Sigma.

\section{Statistical analysis}

Comparison of treatment effects was carried out using one- and two-way analysis of variance techniques as appropriate. Post hoc comparisons of means were performed as necessary. For all statistical tests significance was set at the $5 \%$ level.

\section{Competing interests}

The author(s) declare that they have no competing interests.

\section{Authors' contributions}

$\mathrm{CB}$ was responsible for the conception, planning and performance of experiments and for writing this manuscript. Both MT and AW contributed to the planning of experiments, interpretation of results and the writing of the manuscript.

\section{Acknowledgements}

We thank Dr Aviva Petrie for help in statistical analysis. This research was supported by the European Commission Framework Package 6 Network of Excellence 'NeuroPrion'.

\section{References}

I. Simons M, Keller P, Dichgans J, Schulz JB: Cholesterol and Alzheimer's disease: is there a link? Neurology 200I, 57(6): I089- 1093.

2. Neuhaus O, Stuve O, Zamvil SS, Hartung HP: Evaluation of HMGCoA reductase inhibitors for multiple sclerosis: opportunities and obstacles. CNS Drugs 2005, 19(10):833-41.

3. Fai Mok SW, Thelen KM, Riemer C, Bamme T, Gultner S, Lutjohann $D$, Baier M: Simvastatin prolongs survival times in prion infections of the central nervous system. Biochemical and Biophysical Research Communications 2006, 348(2):697-702.

4. Prusiner SB: Prions. Proc Natl Acad Sci USA 1998, 95(23): | $3363-13383$.

5. Cunningham $C$, Deacon $R$, Wells $H$, Boche $D$, Waters $S$, Diniz $C P$, Scott H, Rawlins JN, Perry VH: Synaptic changes characterize early behavioural signs in the ME7 model of murine prion disease. Eur J Neurosci 2003, I7( I 0):2। 47-2I 55.

6. Jeffrey M, Halliday WG, Bell J, Johnston AR, MacLeod NK, Ingham C, Sayers AR, Brown DA, Fraser JR: Synapse loss associated with abnormal PrP precedes neuronal degeneration in the scrapie-infected murine hippocampus. Neuropathol Appl Neurobiol 2000, 26(I):4I-54.

7. Russelakis-Carneiro M, Hetz C, Maundrell K, Soto C: Prion replication alters the distribution of synaptophysin and caveolin I in neuronal lipid rafts. Am J Pathol 2004, I65(5): I839-1848.

8. Pike LJ: Lipid rafts: heterogeneity on the high seas. Biochem J 2004, 378(Pt 2):28I-292.

9. Ikonen E: Roles of lipid rafts in membrane transport. Curr Opin Cell Biol 200I, 13:470-477.

10. Varma R, Mayor S: GPI-anchored proteins are organized in submicron domains at the cell surface. Nature 1998, 394(6695):798-80।.
II. Vey M, Pilkuhn S, Wille H, Nixon R, DeArmond S], Smart E], Anderson RG, Taraboulos A, Prusiner SB: Subcellular colocalization of the cellular and scrapie prion proteins in caveolae-like membranous domains. Proc Natl Acad Sci USA 1996, 93(25): 14945-14949.

12. Rothberg KG, Ying YS, Kamen BA, Anderson RG: Cholesterol controls the clustering of the glycophospholipid-anchored membrane receptor for 5-methyltetrahydrofolate. J Cell Biol 1990, I I I(6 Pt 2):293 I-2938.

13. Bilderback TR, Grigsby RJ, Dobrowsky RT: Association of p75(NTR) with caveolin and localization of neurotrophininduced sphingomyelin hydrolysis to caveolae. Journal of Biological Chemistry 1997, 272(16): 10922-10927.

14. Baenziger JE, Morris ML, Darsaut TE, Ryan SE: Effect of membrane lipid composition on the conformational equilibria of the nicotinic acetylcholine receptor. Journal of Biological Chemistry 2000, 275(2):777-784.

15. Sooksawate T, Simmonds MA: Effects of membrane cholesterol on the sensitivity of the GABA(A) receptor to GABA in acutely dissociated rat hippocampal neurones. Neuropharmacology 200I, 40(2): I78-I84.

16. Li S, Couet J, Lisanti MP: Src Tyrosine Kinases, Galpha Subunits, and H-Ras Share a Common Membrane-anchored Scaffolding Protein, Caveolin. Caveolin binding negatively regulates the auto-activation of Src tyrosine kinases. Journal of Biological Chemistry 1996, 27 I(46):29182-29190.

17. Cooper DMF, Crossthwaite AJ: Higher-order organization and regulation of adenylyl cyclases. Trends in Pharmacological Sciences 2006, 27(8):426-43I.

18. Oh P, Schnitzer JE: Segregation of heterotrimeric $\mathbf{G}$ proteins in cell surface microdomains. $G(q)$ binds caveolin to concentrate in caveolae, whereas $\mathbf{G}(\mathrm{i})$ and $\mathbf{G}(\mathrm{s})$ target lipid rafts by default. Mol Biol Cell 200I, I 2(3):685-698.

19. Graziani AV, Bricko V, Carmignani M, Graier WF, Groschner K: Cholesterol- and caveolin-rich membrane domains are essential for phospholipase A(2)-dependent EDHF formation. Cardiovasc Res 2004, 64(2):234-242.

20. Simons K, Toomre D: Lipid rafts and signal transduction. Nat Rev Mol Cell Biol 2000, I(I):3I-39.

21. Bate C, Salmona M, Williams A: The role of platelet activating factor in prion and amyloid- $\beta$ neurotoxicity. Neuroreport 2004, 15:509-513.

22. Nordstrom EK, Luhr KM, Ibanez C, Kristensson K: Inhibitors of the Mitogen-Activated Protein Kinase Kinase I/2 Signaling Pathway Clear Prion-Infected Cells from PrPSc. Journal of Neuroscience 2005, 25(37):845I-8456.

23. Alberts AW, Chen J, Kuron G, Hunt V, Huff J, Hoffman C, Rothrock J, Lopez M, Joshua H, Harris E, Patchett A, Monaghan R, Currie S, Stapley E, Albers-Schonberg G, Hensens O, Hirshfield J, Hoogsteen K, Liesch J, Springer J: Mevinolin: a highly potent competitive inhibitor of hydroxymethylglutaryl-coenzyme A reductase and a cholesterol-lowering agent. Proc Natl Acad Sci USA 1980, 77(7):3957-3961.

24. Simons K, lkonen E: Functional rafts in cell membranes. Nature 1997, 387:569-572.

25. Bate C, Reid S, Williams A: Phospholipase A2 inhibitors or platelet activating factor antagonists prevent prion replication. Journal of Biological Chemistry 2004, 279:36405-364II.

26. Diomede L, Forloni G, Bugiani O, Tagliavini F, Salmona M: The prion protein and cellular cholesterol homeostasis. Neurobiology of lipids 2002, I(3):

27. Chang TY, Chang aC, Cheng D: ACYL-COENZYME A:CHOLESTEROL ACYLTRANSFERASE. Annual Review of Biochemistry 1997, 66(I):613-638.

28. Schroeder F, Gallegos AM, Atshaves BP, Storey SM, Mclntosh AL, Petrescu AD, Huang H, Starodub O, Chao H, Yang H, Frolov A, Kier $A B$ : Recent Advances in Membrane Microdomains: Rafts, Caveolae, and Intracellular Cholesterol Trafficking. Experimental Biology and Medicine 200I, 226( I0):873-890.

29. Massimino ML, Griffoni C, Spisni E, Toni M, Tomasi V: Involvement of caveolae and caveolae-like domains in signalling, cell survival and angiogenesis. Cell Signal 2002, I 4(2):93-98.

30. Schmitt-Ulms G, Legname G, Baldwin MA, Ball HL, Bradon N, Bosque PJ, Crossin KL, Edelman GM, DeArmond SJ, Cohen FE, Prusiner SB: Binding of neural cell adhesion molecules (N-CAMs) to the cellular prion protein. J Mol Biol 200I, 3 I 4(5): I 209-I225. 
31. Pfrieger FW: Role of cholesterol in synapse formation and function. Biochimica et Biophysica Acta (BBA) - Biomembranes 2003, $1610(2): 27 \mid-280$.

32. Sandberg MK, Low P: Altered Interaction and Expression of Proteins Involved in Neurosecretion in Scrapie-infected GTI-I Cells. Journal of Biological Chemistry 2005, 280(2): | 264- I 27 I.

33. Gyllberg H, Lofgren K, Lindegren H, Bedecs K: Increased Src kinase level results in increased protein tyrosine phosphorylation in scrapie-infected neuronal cell lines. FEBS Letters 2006, 580(I I):2603-2608.

34. Bate C, Salmona M, Diomede L, Williams A: Squalestatin cures prion-infected neurones and protects against prion neurotoxicity. Journal of Biological Chemistry 2004, 279: I4983-I4990.

35. Liu J, Takano T, Papillon J, Khadir A, Cybulsky AV: Cytosolic phospholipase A2-alpha associates with plasma membrane, endoplasmic reticulum and nuclear membrane in glomerular epithelial cells. Biochem J 200I, 353(Pt I):79-90.

36. Williams AE, Van Dam AM, Man AHW, Berkenbosch F, Eikelenboom $P$, Fraser $H$ : Cytokines, prostaglandins and lipocortin-I are present in the brains of scrapie-infected mice. Brain Res 1994, 654(2):200-206.

37. Minghetti L, Cardone F, Greco A, Puopolo M, Levi G, Green AJ, Knight R, Pocchiari M: Increased CSF levels of prostaglandin E(2) in variant Creutzfeldt-Jakob disease. Neurology 2002, 58(I): $127-129$.

Publish with Bio Med Central and every scientist can read your work free of charge

"BioMed Central will be the most significant development for disseminating the results of biomedical research in our lifetime. "

Sir Paul Nurse, Cancer Research UK

Your research papers will be:

- available free of charge to the entire biomedical community

- peer reviewed and published immediately upon acceptance

- cited in PubMed and archived on PubMed Central

- yours - you keep the copyright

Submit your manuscript here:

http://www.biomedcentral.com/info/publishing_adv.asp 